\title{
Perioperative Uses of Histamine Antagonists
}

\section{Wilfried Lorenz, MD,* Madeleine Ennis, PhD, $\dagger$ Alfred Doenicke, MD, $\neq$ and Wolfgang Dick, MD $\S$}

Institute for Theoretical Surgery, Clinic of the Philipps University Marburg, Marburg, FRG.

Histamine release and adverse pseudoallergiclallergic reactions during the perioperative period occur frequently. The incidence of such reactions is $20 \%-30 \%$ for all grades of severity, $1 \%-5 \%$ for systemic reactions, and $0.1 \%-0.5 \%$ for life-threatening reactions. They can be elicited by all commonly used anesthetic agents and by surgical interventions. Both the incidence and severity can be reduced by the

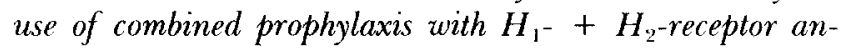
tagonists. The authors recommend that this prophylaxis be given to the following groups of patients: those with a history of adverse reactions or history of allergy, patients undergoing surgery with a high risk of histamine release, elderly patients,

*Professor of Theoretical Surgery, University of Marburg, FRG

$\nmid$ Postdoctoral Research Assistant, University of Marburg, FRG

\$Professor of Anesthesia, Institute of Anesthesiology, Ludwig Maximilians University of Munich, FRG

\$Professor of Anesthesia, Anesthesiological Clinic, University of Mainz, FRG

Address reprint requests to Professor Lorenz at the Institute for Theoretical Surgery, Centre for Operative Medicine I, Baldingerstrasse, D-3550 Marburg, Federal Republic of Germany.

This work was supported by a grant of the Deutsche Forschungsgemeinschaft (Lo 199/16-1).

Received for publication August 11, 1989; revised manuscript accepted for publication June 8, 1990.

(C) 1990 Butterworth-Heinemann and those with poor physical status due to underlying systemic diseases. These indications have been developed by heuristic medical decision-making, including a decision tree.

Keywords: Drugs, adverse reactions; risk factors; histamine; histamine antagonists; allergy; anesthesia.

\section{Introduction}

Histamine release and undesired histamine release reactions during anesthesia and surgery have been the subject of extensive and persistent research in anesthesiology, ${ }^{1-11}$ pharmacology, ${ }^{1-11}$ and clinical immunology $y^{15-18}$ over the last 20 years. This activity stands in marked contrast to the regrettable fact that the wealth of consistent data in this field ${ }^{1-18}$ is not widely appreciated by anesthesiologists in daily practicc. Unwanted histamine release reactions appear clinically as pseudoallergic and allergic reactions ${ }^{17}$ but also as "atypical" disease entities such as significant arrhythmias, hypertension, myocardial infarction, ${ }^{19,211}$ vomiting and diarrhea, ${ }^{19}$ and thrombosis." The reactions are caused by the administration of several drugs during anesthesia ${ }^{21}$ and by various physical actions, e.g., intubation ${ }^{22}$ and measures of surgical intervention." They occur more frequently than is generally supposed. Using data obtained from prospective clinical trials, the overall incidence of reactions is about $20 \%-30 \%$, including increased gastric acid secretion. ${ }^{1.23}$ Systemic reactions occur in $1 \%-5 \%$, and life-threatening reactions occur in $0.1 \%-0.5 \%$ of patients. ${ }^{21}$

J. Clin. Anesth., vol. '2, September/Uctober 1990 
Why don't many countries accept the fact that antihistamines should be given to some groups of surgical patients? A language barrier could be at fault. The first report associating increased plasma histamine concentrations and clinical symptoms after administration of the hypnotics thiopental sodium and propanidid (Epontol ${ }^{(B)}$ ) in routine anesthesia was published in 1970. ${ }^{24}$ Based on data from a randomized clinical trial, the same group first demonstrated that adverse pseudoallergic reactions could be prevented completely by administering histamine $\mathrm{H}_{1^{-}}+\mathrm{H}_{2^{-}}$ receptor antagonists. ${ }^{25}$ However, since that trial more than 10 years ago, ${ }^{25}$ this subject has been discussed without definitive resolution, a situation that now has led to an international multicenter trial. ${ }^{26,27}$

In this review, the incidence of adverse pseudoallergic and allergic reactions seen during anesthesia and surgery is addressed, as are the pharmacology of $\mathrm{H}_{1-}+\mathrm{H}_{2}$-antihistamines and the current state of the art regarding the effectiveness of a combined prophylaxis with $\mathrm{H}_{1^{-}}+\mathrm{H}_{2}$-receptor antagonists. Finally, a decision tree for a problem solving strategy leading to recommendations for the use of $\mathrm{H}_{1}-+\mathrm{H}_{2}$-blockade as a systematic approach to prevent or reduce the severity of such reactions is presented.

\section{Histamine Release Reactions, Allergic and Pseudoallergic Reactions: Classification by Pathomechanisms}

Histamine release reactions in anesthesia and surgery, ${ }^{28}$ also those reactions to intubation and surgical trauma if the extent of histamine release elicited causes clinical symptoms, ${ }^{21}$ are a subset of adverse responses resembling hypersensitivity reactions. The latter are classified either as allergic (involving immune processes) or pseudoallergic (in which the immune system is not involved or its involvement has not been demonstrated) (Table 1). ${ }^{29}$ Both allergic and pseudoallergic reactions can present with the same clinical symptoms; however, no previous contact is required in pseudoallergic reactions. More than one mechanism may be involved in reactions to a single drug. Thus, in reactions involving thiopental, $20 \%$ are allergic type I, $10 \%$ are allergic reactions involving complement, $4 \%$ are pseudoallergic reactions involving the alternate pathway for complement activation, and $64 \%$ are caused by other pseudoallergic mechanisms, mostly type $I^{30}$

Among the allergic reactions (Table 1), types I and III are predominant in the adverse drug reactions observed in anesthesia. ${ }^{30}$ Type I allergic reactions result from the crosslinking of cell-bound immunoglobulin (IgE) on mast cells or basophils by antigen. These cells then release a host of mediators including histamine, prostaglandins, leukotrienes, platelet activating factor, and chemotactic factors. Hence, the causal role of histamine must be analyzed in those reactions. ${ }^{31}$ Adverse responses caused by thiopental, neuromuscular blocking agents, or chymopapain can be via a type I allergic mechanism. ${ }^{8}$ In type III allergic reactions, the antigen-antibody complex causes complement activation that also leads to mast cell degranulation via several anaphylatoxins. In addition, polymorphs are attracted, platelet activation occurs

Table 1. Classification of Allergic and Pseudoallergic Reactions by Pathomechanisms

\begin{tabular}{|c|c|}
\hline Allergic & Pseudoallergic \\
\hline Type I: Anaphylactic & Type I: $\Lambda$ naphylactoid \\
\hline $\begin{array}{l}\text { Antigen reacts with cell-bound IgE (occasionally } \\
\text { IgG subclasses). }\end{array}$ & $\begin{array}{l}\text { Compound stimulates mast cell or basophil secretion by acting } \\
\text { directly at receptors, by releasing or forming mediators, or by } \\
\text { modulating second-messenger systems. }\end{array}$ \\
\hline Type II: Antibody-dependent cytotoxic & Type 1I: Cytotoxic pseudoallergic \\
\hline Antibodies bind to cell-bound antigens. & $\begin{array}{l}\text { Compound causes cell danage or cycolysis by direct effects on } \\
\text { membranes and/or other cell components, or by activating } \\
\text { cytotoxic mediator systems (alternate pathway, coagulation } \\
\text { and fibrinolysis, elastase, etc.). }\end{array}$ \\
\hline Type III: Complex-mediated & Type III: Complex-mediated pseudoallergic \\
\hline $\begin{array}{l}\text { Circulating antigens and antibodies combine to } \\
\text { form complexes. }\end{array}$ & $\begin{array}{l}\text { Compound binds to membranes and/or circulating cells } \\
\text { (thrombocytes, etc.) to activate the alternate pathway of the } \\
\text { complement system. }\end{array}$ \\
\hline Type IV: Cell-mediated (delayed) & Type IV: Cell-mediated (delayed) pseudoallergic \\
\hline $\begin{array}{l}\text { Antigen reacts with endogenous receptors on } \\
\text { primed 'T lymphocytes. }\end{array}$ & $\begin{array}{l}\text { Compound elicits the clinical picture by acting at receptors or } \\
\text { cell membranes of } 1 \text { lymphocytes or macrophages. }\end{array}$ \\
\hline
\end{tabular}

From Ennis and Lorenz ${ }^{29}$ with permission. 
with mediator release, and the formation of microthrombi and macrophages are activated. Such reactions are observed, for instance, after dextran, contrast media, or protamine administration. . $^{814,31}$

Among the pseudoallergic reactions (Table 1), those of type I predominate in anesthesia and surgery. Direct release of histamine from mast cells or basophils has been demonstrated for many agents, including opioids, hypnotics, muscle relaxants, plasma substitutes, antibiotics, and radiographic contrast media. 6.8 .14 The solvents or other agents in formulation for intravenous (IV) use can also directly release histamine. For instance, cremophor $\mathbf{E l}^{\circledR}$ is still used as a solubilizer in formulations of steroid hormones, $c y$ closporin A, glycerol trinitrate antibiotics, vitamins, among others, and was also included in the formulations of propanidid and althesin, which have been removed from the market because of the unacceptably high incidence of reactions. ${ }^{2.21,22.29}$ Cremophor El ${ }^{\text {w }}$ cannot only directly release histamine from some mast cell types but may also modulate (potentiate or inhibit) the histamine release caused by other agents." Histamine can be directly administered to the patient during blood transfusions and in coronary bypass sur775gery. ${ }^{21.3 \%}$ Histamine impurities in commercial heparin also can lead to the direct administration of histamine to the patient. ${ }^{3-4}$ The histamine content of 15 clinically used heparin samples from 5 companies varied 50-fold (Table 2). Using a dose of $400 \mathrm{IU} / \mathrm{kg}$ applied as a bolus, about $\mathbf{3 4 0} \mathrm{ng}$ histamine could be administered to the heart and cause the symptoms observed by Adt et al." Disruption of mast cells (e.g., mechanically through surgical trauma) also causes histamine release." Finally, histamine also can be released by activation of the alternate pathway of the complement cascade ${ }^{5}$ via insoluble protein complexes, talcum powder, or tissue detritus as a type III pseudoallergic mechanism (Table l).

Thus, there are many mechanisms that can elicit adverse histamine release reactions. Only by combination of in vitro studies, in vivo animal trials with designs based on the clinical situation, volunteer trials, and prospective controlled clinical trials can the mechanisms be elucidated. ${ }^{29}$ An understanding of the underlying mechanisms can lead to product improvement and hence a reduction in the incidence and/or severity of reactions. ${ }^{21.29}$

\section{Diagnostic Predictors of Histamine Release Reactions}

Clinical judgment on incidence, severity, and clinical relevance of these reactions depends strongly on the
Table 2. Histamine Content in Different Clinical Preparations, Batches, and Pharmaceutical Formulations of Heparin

\begin{tabular}{cc}
\hline $\begin{array}{c}\text { Heparin Preparation } \\
\text { Number }\end{array}$ & $\begin{array}{c}\text { Histamine Content } \\
\text { (pg/IU) }\end{array}$ \\
\hline 1 & 1.34 \\
2 & 6.22 \\
3 & 0.90 \\
4 & 3.60 \\
5 & 0.40 \\
6 & 9.62 \\
7 & 6.22 \\
8 & 0.24 \\
9 & 13.44 \\
10 & 5.00 \\
11 & 11.64 \\
12 & 0.44 \\
13 & 6.04 \\
14 & 0.72 \\
15 & 4.55 \\
Median & 4.55 \\
(range) & $0.24-13.44$ \\
\hline
\end{tabular}

$\mathrm{pg} / \mathrm{IU}=$ picogram/international unit.

The heparin preparations were obtained from the following companies: Braun Melsungen, 3508 Melsungen (FRG); Hoffmann-La Roche, 7889 Grenzach-Wyhlen (FRG); Nordmark, 2082 Uetersen (Holstein) (FRG); Organon, 8042 Oberschleißheim (FRG); Ratio pharm, 7902 Blaubeuren (FRG).

All values are the means of 3 determinations. Histamine was measured by the combined fluorometric technique. ${ }^{22.14}$

improved accuracy in diagnosing them in the clinical scenario of operative medicine. ${ }^{28}$ Methods of objective medical decision making (decision matrix, receiveroperating characteristic curve, ${ }^{28}$ independence Bayes, and step-wise logistic regression ${ }^{35}$ ) were combined with randomized clinical trials, ${ }^{25,36}$ histamine injection, ${ }^{12,28}$ and infusion ${ }^{1.37,38}$ techniques in human volunteers, administration of exogenous histanine and histamine releasers to the same subject within 30 minutes, ${ }^{28,39}$ and plasma histamine assays in combination with prophylactic application of $\mathrm{H}_{1^{-}}+\mathrm{H}_{2}$-antagonists. ${ }^{25,37,38}$ The result was a set of predictors for diagnosing histamine release reactions that differs considerably from the set of predictors found in standard medical teaching (Table 3).

Restriction of the symptoms to skin responses, hypotension, and bronchospasm usually leaves only the skin response, since cardiovascular and respiratory disturbances for various reasons are not uncommon in anesthesia and surgery. This restriction of symptoms may lead to a severe underestimation of the incidence of reactions. Furthermore, since not all agents produce the same set of predictors, the symptoms that can be used to define a reaction also vary 
Table 3. Predictors (Complaints, Clinical Signs. Biological Reactions) Gor Diagnosing Histanine Release Reatenoms listablished in a Variety of Clinical Trials

\begin{tabular}{|c|c|c|c|c|}
\hline Skin & $\begin{array}{c}\text { Gastrointestinal } \\
\text { Tract }\end{array}$ & Respiratory Tract & $\begin{array}{l}\text { Head and Nervous } \\
\text { System }\end{array}$ & $\begin{array}{l}\text { Heart and } \\
\text { Circulation }\end{array}$ \\
\hline $\begin{array}{l}\text { sensation of heat } \\
\text { red ears } \\
\text { erythema } \\
\text { flush } \\
\text { hives (wheals) } \\
\text { pruritus } \\
\text { conjunctivitis } \\
\text { blepharedema } \\
\text { swollen ears } \\
\text { edemal }\end{array}$ & $\begin{array}{l}\text { metallic taste } \\
\text { salivation } \\
\text { heartburn } \\
\text { epigastric fullness } \\
\text { naused } \\
\text { vomiting } \\
\text { gastrointestinal pain } \\
\quad \text { (cramps, colics) } \\
\text { straining } \\
\text { defecation }\end{array}$ & $\begin{array}{l}\text { sneering } \\
\text { snuffling } \\
\text { stuffy nose } \\
\text { nasal catarhea } \\
\text { narrowness in the } \\
\text { lhroat } \\
\text { narrowness in the } \\
\text { chest } \\
\text { coughing } \\
\text { respiratory distress } \\
\text { bronchospasm }\end{array}$ & $\begin{array}{l}\text { tinnitus } \\
\text { congestion in the } \\
\text { head } \\
\text { pulsation in the } \\
\text { remporal region } \\
\text { headache } \\
\text { drowsiness } \\
\text { dizriness } \\
\text { wet eyes/tears } \\
\text { agitation } \\
\text { sensation of hangover }\end{array}$ & $\begin{array}{l}\text { dachy-or bradycardia } \\
\text { disturbed } \\
\text { atrioventricular } \\
\text { conduction } \\
\text { hypo- or } \\
\text { hypertension } \\
\text { circulatory and } \\
\text { cardiat } \\
\text { insulficiency } \\
\text { circulatory and } \\
\text { cadiat anrest }\end{array}$ \\
\hline
\end{tabular}

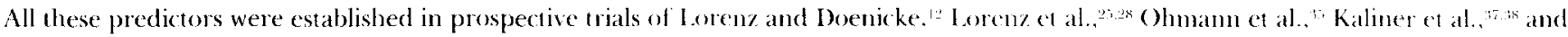
Lorenz et al.:

from drug to drug. In the case of atracurium, these symptoms were cutaneous signs and changes in heart rate (HR) (tachy- and bradycardia). ${ }^{10}$ In the case of polygeline (Haemaccel), the symptoms were tachycardia only and hypertension, whereas flush and erythema were observed in only about $30 \%$ of individuals. ${ }^{28}$ In the case of heparin during cardiac surgery, only arrhythmias ${ }^{34}$ were detected; and histamine release by the $\mathrm{H}_{2}$-antagonist cimetidine and ranitidine was accompanied by metallic taste, headache, changes in HR and blood pressure (BP); ranitidine always caused a pale face, neck, and chest. ${ }^{39}$ The reasons for the different sets of diagnostic predictors are mast cell heterogeneity in their response to different drugs, ${ }^{\prime \prime}$ additional effects of these agents that act as functional or receptor antagonists, ${ }^{42}$ the site and type of application of these agents, and other mediators that are released or formed by the released histamine (e.g., bradycardia induced by noradrenaline release). ${ }^{13}$

In addition to histamine release, these drugs can also cause adverse reactions by other mechanisms ( $e . g$, myocardial depression, ganglionic blockade) and, hence, complicate the accurate diagnosis of the reactions not only by the omission of, but also by the addition of symptoms/signs. ${ }^{40.42}$ Therefore, only one test is available at present for the $95 \%$ accurate diagnosis of a histamine release reaction: increased plasma histamine levels. ${ }^{21,28.40}$

Histamine release reactions can be divided into three grades of severity. ${ }^{28}$ Grade I reactions are local (cutaneous) reactions. The clinical symptoms include erythema, urticaria and/or dermal pruritus only. These reactions are not considered as threatening as the other two grades and no intensified observation or treatment is necessary. The plasma histamine concentra- tions are less than or equal to $1 \mathrm{ng} / \mathrm{ml}$. Grade II reactions are systemic. They include generalized skin reactions plus discomfort, tachy- or bradycardia, other types of arrhythmias, medium hypo- or hypertension, and respiratory distress. These reactions are considered threatening by both the patient and the doctor, and close observation and/or treatment is necessary. Plasma histamine levels are $>1 \mathrm{ng} / \mathrm{ml}$. The life-threatening reactions are grade III. Symptoms observed include severe hypotension, ventricular fibrillations, cardiac arrest, bronchospasm, or respiratory arrest. These reactions are considered life-threatening by the doctor and require emergency treatment. 'I he plasma histamine levels in these patients are $>12 \mathrm{ng} / \mathrm{ml} .{ }^{2 x}$

\section{Situations during the Perioperative Period Leading to Increased Plasma Histamine Levels and Histamine Release Reactions}

Increased plasma histamine concentrations and adverse reactions for which histamine is a necessary, sufficient, or contributing determinant, ${ }^{31}$ occur throughout the perioperative period. ${ }^{11.12 .21 .44}$ These increased histamine levels have been demonstrated in disease states of patients before they enter the operating room (OR), e.g., in polytrauma, ${ }^{45}$ septic shock, ${ }^{40,47}$ upper gastrointestinal (GI) bleeding, ${ }^{47}$ intestinal ischemia, ${ }^{44,48}$ renal failure, ${ }^{21}$ and mastocytosis. ${ }^{21}$ The adverse reactions have been shown in these clinical situations by several methods, since the conditions were very complex for a single mediator in these discase states: multivariate causality analysis in septic shock, ${ }^{44}$ assessment of stress ulceration in polytrauma, ${ }^{21}$ effect 
of $\mathrm{H}_{1^{-}}+\mathrm{H}_{2^{-}}$-antagonists on the survival time in intestinal ischemia. ${ }^{48}$

The measures that occur before surgery and are associated with increased plasma histamine levels include endoscopy ${ }^{49}$ and catheter insertion. ${ }^{11}$ Lindlar et al. ${ }^{49}$ examined four groups of patients scheduled for follow-up endoscopy (esophageal varices, duodenal ulcer, duodenal ulcer after selective proximal vagotomy, and nonspecific abdominal pain). The frequency of increased plasma histamine levels was between $19 \%$ and $28 \%$, the highest occurrence rate being observed in the group with esophageal varices. The highest plasma histamine concentration was $6 \mathrm{ng} / \mathrm{ml}$. If emergency patients with upper GI bleeding then have a histamine release reaction either due to the endoscopy itself ${ }^{47}$ or to any drugs that may be preoperatively given, their reactions may be more severe than in those patients undergoing elective surgery. In an animal model for this hypothesis, it was shown in dogs following blood loss and isovolemic hemodilution ${ }^{\text {t4 }}$ that the same histamine release was much less tolerated than in normal, unpretreated animals, and was associated with considerable mortality.

The most dangerous period for histamine release reactions, however, is at anesthesia induction (Table 4). 1.21,28,31,34.39,50-61 All of the drugs used can cause increased plasma histamine levels and also unwanted histamine release reactions including, at the minimum, increased gastric secretion ${ }^{23}$ and cardiac dysrhythmias ${ }^{20}$ as the most sensitive responses to histamine. In addition, all other drugs administered for the prevention of surgical complications, such as heparin, ${ }^{34}$ protamine, ${ }^{62.63}$ and antibiotics such as vancomycin, ${ }^{64}$ metronidazole, and cephalosporines, ${ }^{6.5}$ can also cause histamine release and adverse reactions. The vast range of agents causing histamine release and reactions and the relatively high incidence of such events (Table 4) should serve as a warning, since all of these drugs are used routinely. In severely ill patients, even a minor $(<1 \mathrm{ng} / \mathrm{ml})$ or medium $(1-10$ $\mathrm{ng} / \mathrm{ml}$ ) plasma histamine level otherwise well tolerated by a healthy person, in combination with other mechanisms or mediators such as in polytrauma, ${ }^{91.45}$ septic shock, ${ }^{+4.46}$ or following bone cement implantation in an elderly patient, ${ }^{55}$ can lead to death, as multivariate causality analysis has shown. ${ }^{44,47}$

Furthermore, the modulation of histamine release through administration of a mixture of drugs at anesthesia induction ${ }^{26}$ must be considered. Thus, drugs which alone release little or no histamine may cause medium or severe reactions in combination with other agents. ${ }^{32}$ Although etomidate rarely releases histamine when given alone, the authors found that when it was given after muscle relaxants, the timing of the adverse reactions suggested that etomidate might itself have caused some histamine release. ${ }^{58}$ Similar findings were observed after lormetazepam administration was followed by etomidate. ${ }^{60}$ In a randomized trial, 24 patients received either nalbuphine or fentanyl as analgesics during routine anesthesia. ${ }^{66}$ Five of 11 patients had increased plasma histamine levels after fentanyl, and 6 of 13 patients after nalbuphine. However, after induction of anesthesia with alcuronium, flunitrazepam, and thiopental, only 1 patient had increased plasma histamine levels in the fentanyl group, but 6 patients had increased plasma histamine levels in the nalbuphine group $(p<0.05)$.

Surgical procedures themselves, in phases independent of anesthesiological measures, release histamine. ${ }^{21.41,51,67,68}$ In five standard operations (thyroidectomy, lobectomy or pneumectomy, cholecystectomy, anterior colorectal resection, and aorto-femoral bypass operation), increased plasma histamine concentrations were found during one or more defined phases such as body cavity exploration and detachment of adhesions. ${ }^{68}$ Other surgical interventions producing increased plasma histamine levels include resection of liver segments and the esophagus, ${ }^{69}$ kidney and liver transplantation, ${ }^{21}$ aneurysmal clipping, ${ }^{70}$ pediatric cardiopulmonary bypass, ${ }^{71}$ and bone cement implantation ${ }^{55.72}$

A special situation during surgery in which free histamine is infused via a central catheter directly into the heart and the pulmonal circulation is the administration of erythrocyte concentrates for blood transfusion. Histamine concentrations are high in the "plasma supernatant" of these infusion mixtures, especially toward the end of administration when high pressure is applied to push the residual blood through the stuffed filters (Figure 1). ${ }^{\text {is }}$

\section{Pharmacology of Histamine Receptor Antagonists: Pharmacokinetics and Adverse Reactions}

\section{Histamine Receptors}

Histamine exerts its physiological actions by binding to specific receptors. ${ }^{73}$ Three receptor types for histamine have been found: $\mathrm{H}_{1}, \mathrm{H}_{2}$, and $\mathrm{H}_{3}$. These receptors are defined pharmacologically by the actions of their agonists and antagonists. Histamine via the $\mathrm{H}_{1}$ receptors mediates the following biological effects in humans: decrease in atrioventricular node conductance, coronary artery constriction, vasoconstriction (blood vessels $>80 \mu \mathrm{m}$ ), vasodilation (blood vessels 
Table 4. Drugs that Cause Increased Plasma Histamine Levels and Adverse Reactions as Demonstrated in Clinical Trials with Volunteers or Patients

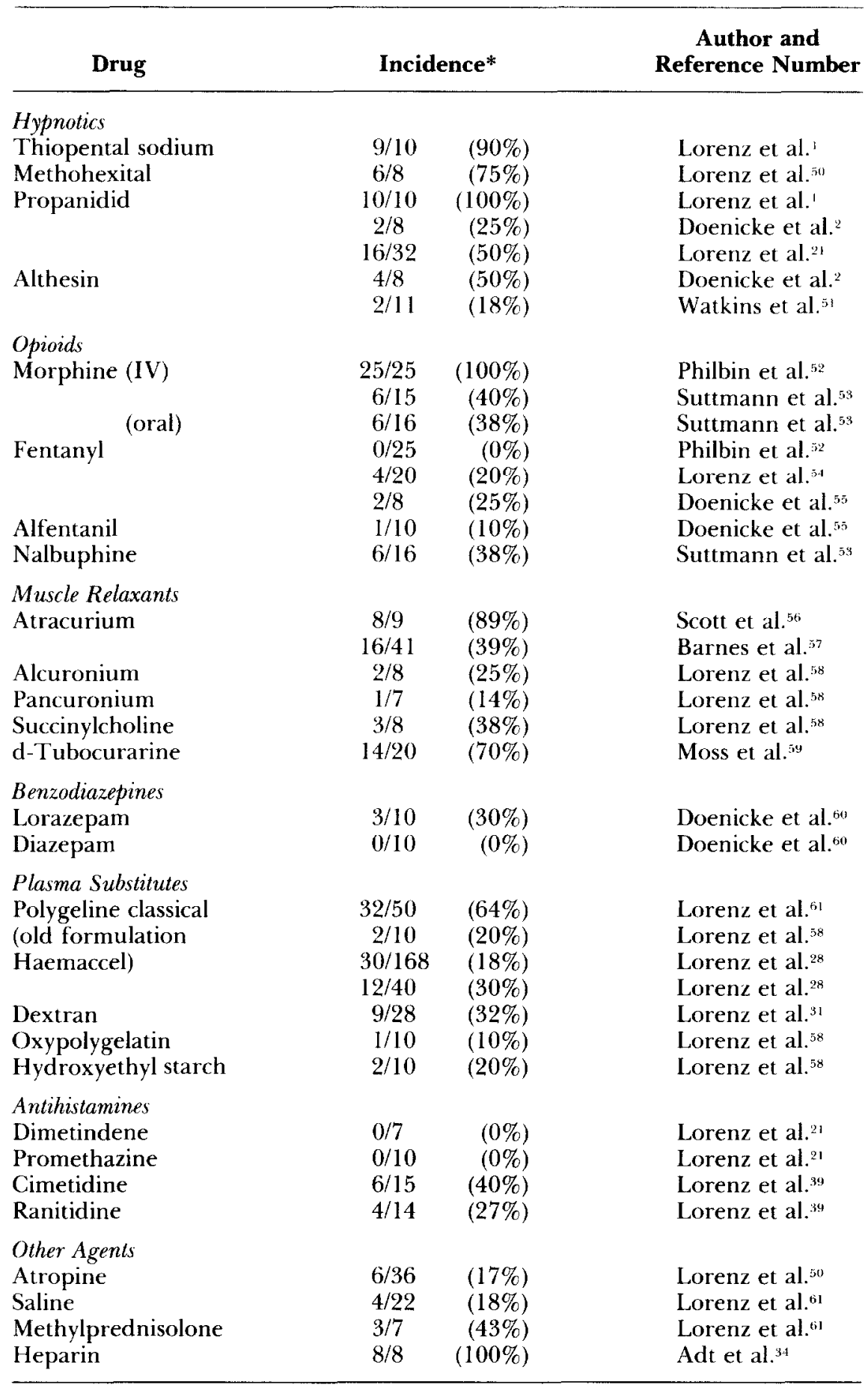

*Incidence of increased plasma histamine levels.

$\mathrm{IV}=$ intravenous.

$<80 \mu \mathrm{m}$ ), increased vascular permeability, pruritus, bronchial constriction, activation of airway vagal afferent nerves, smooth muscle contraction in the GI tract, and release of catecholamines from the adrenal medulla. ${ }^{13,74,75}$
The actions via $\mathrm{H}_{2}$ receptors include increase in HR and myocardial contractility, coronary vasodilation, peripheral vasodilation (blood vessels $<80 \mu \mathrm{m}$ ), bronchial dilation, increase in airway mucus secretion, esophageal contraction, and gastric acid secretion. The 


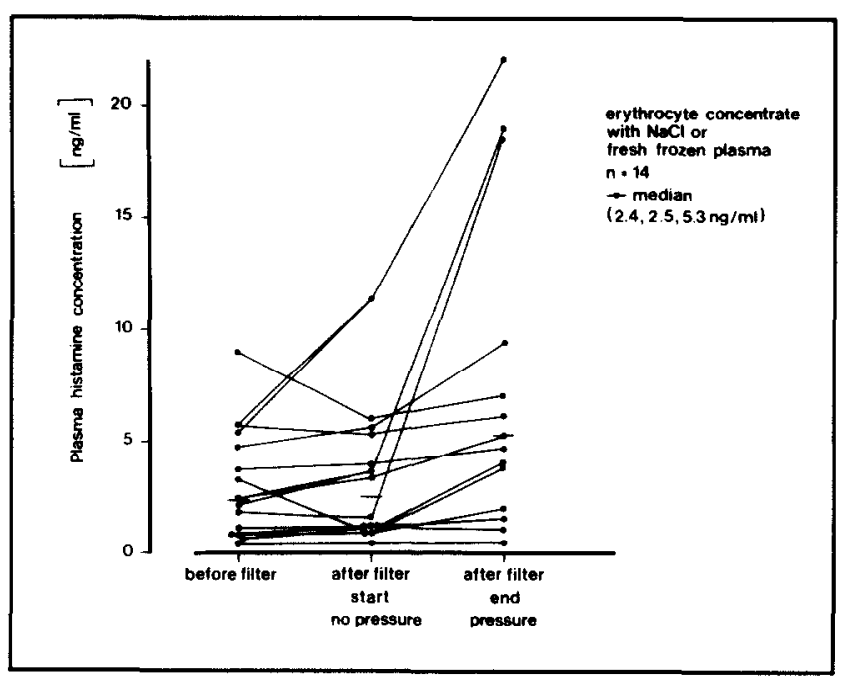

Figure 1. Histamine concentrations in the "plasma supernatant" of erythrocyte concentrates used for blood transfusion in the study of Röher et al. ${ }^{\text {bx }}$ Units of concentrates were obtained from a local blood bank, dissolved in saline or fresh frozen plasma immediately before use, and passed through at $10 \mu \mathrm{m}$ microfilter. $\mathrm{NaCl}=$ sodium chloride.

combined action of histamine on $\mathrm{H}_{1}$ and $\mathrm{H}_{2}$ receptors in an additive way mediates hypotension and decrease in systemic vascular resistance (SVR), flushing, and headache. In addition, histamine $\mathrm{H}_{1}$ and $\mathrm{H}_{2}$ receptors are found in many blood cells: T-cells (suppressor $\mathrm{T}$ cells, hclper T cells, cytotoxic T cells $\left.\left(\mathrm{H}_{2}\right)\right)$, B cells $\left(\mathrm{H}_{1}\right)$, neutrophils, basophils, eosinophils, and monocytes. In the brain, both $\mathbf{H}_{1}$ and $\mathrm{H}_{2}$ receptors have been found; indeed, mammalian brain has the highest density of $\mathrm{H}_{1}$ binding sites of any organ studied..$^{13,74-76}$

Recently, the $\mathrm{H}_{3}$ receptor, which is involved in the feedback control of histamine release from presynaptic sites, has been described. ${ }^{77}$ Its presence also has been described in rat brain and lung. However, a function for these receptors has not yet been shown to be involved in anesthesia and surgery. Hence, the remainder of the article focuses only on $\mathrm{H}_{1}$ and $\mathrm{H}_{2}$ receptor antagonists.

\section{Histamine $H_{1}$ Receptor Antagonists}

An exceedingly large number of $\mathrm{H}_{1}$ receptor antagonists are available; however, only a few have been used in anesthesia and surgery. This situation is mainly due to their lipophilic properties; since they are insoluble in water, they are not available for IV administration. The authors, therefore, concentrate on those agents most commonly used in different countries: chlorpheniramine, dimetindene, hydroxyzine, clemastine, and promethazine. Most of these preparations have been available for 20-30 years and few formal pharmacokinetic studies have been performed, especially after IV administration (Table 5). ${ }^{13.78 .79}$ However, data on blood levels are insufficient to provide information on the rapidity of onset of the protection, effectiveness of this protection against lifethreatening reactions, and duration of this protection. The binding to the histamine receptors and, after signal-transducing, the final biological reaction, are obviously the most important features. These data are available only from two published studies in dogs ${ }^{21,80}$ (Table 6). Against life-threatening reactions with plasma histamine levels comparable to those in human subjects, ${ }^{1.6,21.55}$ the $I_{1}$-receptor antagonist is less effective (about one-half as effective) than the combined $\mathrm{H}_{1^{-}}$ $1 \mathrm{H}_{2}$-prophylaxis. The prophylaxis is protective if administered 15 minutes before the substance producing the adverse reaction and also protective after 2 hours. Methylprednisolone, even administered 2 hours before the histamine releaser, was incffective in the low dose and worse than placebo in the high dose.

Table 5. Pharmacokinetic Data for Histamine $\mathbf{H}_{1^{-}}+\mathrm{H}_{2^{-}}$-Receptor Antagonists

\begin{tabular}{|c|c|c|c|c|}
\hline \multirow[b]{2}{*}{ Pharmacokinetic Parameter } & \multicolumn{2}{|c|}{$H_{1}-$ Receptor Antagonists } & \multicolumn{2}{|c|}{$\mathrm{H}_{2}$-Receptor Antagonists } \\
\hline & Hydroxyzine & Dimetindene & Cimetidine & Ranitidine \\
\hline Bioavailability (f, \%) & - & 74 & 62 & 52 \\
\hline Volume of distribution $\left(V_{s s}, 1\right)$ & 16 & 184 & 70 & 126 \\
\hline Total body clearance $(\mathrm{Cl}, \mathrm{l})$ & $41-69$ & 26 & 32 & 42 \\
\hline Elimination half-life (t $1 / 2, \mathrm{~h}$ ) & $14-20$ & 5 & 2 & 2 \\
\hline
\end{tabular}

Data compiled from refs. 78,79 for hydroxyzine, from Arnera V (Zyma, Nyon (Switzerland)) for dimetindene, and from ref. 13 for cimetidine and ranitidine. Volume of distribution and total body clearance calculated for a human subject of $70 \mathrm{~kg}$. Bioavailability after oral administration. 
Table 6. Life-Threatening Histamine Release Reactions in Dogs in a Model for Pseudoallergic Reactions to Plasma Substitutes: Influence of $\mathbf{H}_{1^{-}}+\mathbf{H}_{2^{-}}$ receptor Antagonists and Low-Dose and High-Dose Methylprednisolone on Hypotension and Histamine Release

$\begin{array}{lcc}\text { Hypotension } & \text { Increase in Plasma Histamine } \\ \text { Prophylaxis } & (\mathrm{mmHg}, \tilde{\mathbf{x}} \text { (range) }) & (\mathbf{n g} / \mathbf{m l}, \tilde{\mathbf{x}} \text { (range) }\end{array}$

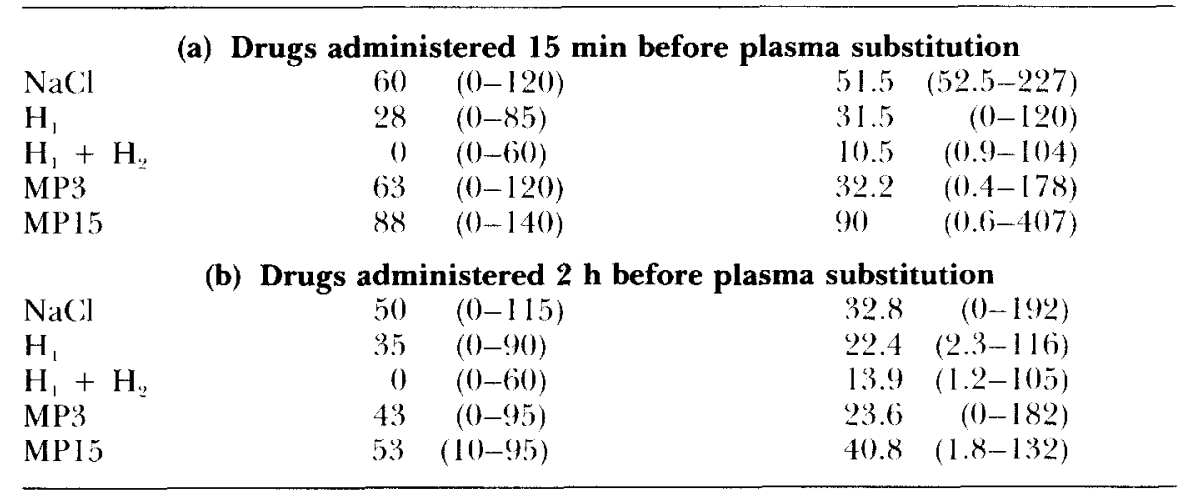

Maximum hypotension (systolic blood pressure $5-8$ min after starting inf usion) and histamine release at this time following bleeding of one-third of blood volume and I min later plasma substitution by Ringer containing $50 \mu \mathrm{g} / \mathrm{kg} 48 / 80$ as a typical histamine releaser. As in human studies, ${ }^{28}$ not all animals react to the histamine releaser, but only a proven portion (large range!). $\mathrm{NaCl}=$ sodium chloride $; \mathrm{H}_{1}=0.5 \mathrm{mg} / \mathrm{kg}$ dimentidene; $\mathrm{H}_{2}=5 \mathrm{mg} / \mathrm{kg}$ cimetidine: MP3 $-3 \mathrm{mg} / \mathrm{kg}$ methylprednisolone: MP15 $=15 \mathrm{mg} / \mathrm{kg}$ methylprednisolone. Randomized double-blind trial, 12 animals/group. Basal plasma histamine level $0.3 \mathrm{ng} / \mathrm{ml}$ as in humans. From Dietz et al., ${ }^{(1)}$ with permission.

All $\mathrm{H}_{1}$-receptor antagonists have many effects in addition to their "specific" antihistaminic property. ${ }^{13.81,82}$ Some of these effects are beneficial in pseudoallergic and allergic reactions if they attenuate the effects of other mediators such as serotonin and bradykinin. ${ }^{81}$ However, most of these drugs act on the central nervous system (CNS), with both stimulation and depression being observed. ${ }^{13,82}$ For example, chlorpheniramine produces stimulation and clemastine fumarate often causes drowsiness. Dimetindene elicits only little sedation, as shown by several psychometric tests and electroencephalographic (EEG) analysis. $^{21}$ Hydroxyzine is a long-acting compound (Table 5) with considerable central depressant activity. However, when given with morphine for postoperative pain, hydroxyzine provides better pain relief than does morphine alone. ${ }^{83}$ Promethazine hydrochloride is the most sedating agent of its group ${ }^{13}$ and is still often used for its antiemetic affects. It potentiates the action of the narcotics morphine, pethidine, fentanyl, and pentazocine ${ }^{84}$ Some of these $\mathrm{H}_{1}$-receptor antagonist side-effects on the CNS may be judged differently in anesthesiology than in other medical disciplines. Sedation or potentiation of the effects of other drugs may be welcomed. However, these effects should always be considered.

\section{Histamine $\mathrm{H}_{2}$ Receptor Antagonists}

Until now, two commercially available $\mathrm{H}_{2}$ receptor antagonists, cimetidine and ranitidine, have been used in the perioperative period. A wealth of pharmacokinetic data is available (Table 5), but, again, the binding of the compounds to histamine receptors is a more important feature (Table 6) than is the pharmacokinetic data based on plasma levels.

$\mathrm{H}_{2}$-receptor antagonists have side effects in addition to their desired actions. However, adverse reactions to these agents are extremely rare and have been observed only after repeated and chronic use, e.g., agranulocytosis or hypothalamic-pituitary-gonadal dysfunction..$^{85}$ There are, however, findings that must be considered by the anesthesiologist:

1. Hemodynamic effects: Rapid IV administration of $\mathrm{H}_{2}$-receptor antagonists should be avoided. It leads to histamine release and, hence, bradycardia, hypotension, and other cardiotoxic effects. ${ }^{39}$ This reaction is not seen after slow infusion. ${ }^{61}$

2. Drug interaction: Both cimetidine and ranitidine bind to cytochrome P450 but the binding is weaker for ranitidine. ' $I$ 'his fact can lead to accumulation of drugs that undergo oxidative degradation, e.g., warfarin, diazepam, theophylline, phenytoin, carbama- 
zepine, lidocaine, propranolol. ${ }^{86}$ However, there are always other drugs from the pharmacological class that can be substituted, thus eliminating the problem (e.g., substituting oxazepam or lorazepam for diazepam, using nadolol or atenolol instead of propranolol. $)^{\mathrm{N}-4}$

3. Neuromuscular effects: The anticholinesterase and/ or ganglionic blocking activity of the $\mathrm{H}_{2}$-receptor antagonists might influence the cardiovascular status of the anesthetized patient. ${ }^{87}$ However, their pharmacological effects at cholinergic sites have heen observed only at high drug doses. Cimetidine has no effect on succinylcholine-induced neuromuscular blockade. ${ }^{88}$ Cimetidine (not ranitidine) prolongs the effect of vecuronium. The action of the $\mathrm{H}_{2}$-receptor antagonists on bupivacaine pharmacokinetics has been described as without effect ${ }^{89}$ or with a reduced bupivacaine clearance after cimetidine. ${ }^{90} \mathrm{H}_{2}$-receptor antagonists have no effect on lidocaine concentrations during epidurals. ${ }^{.1}$

4. Gastrointestinal effects: The administration of $\mathbf{H}_{2^{-}}$ receptor antagonists in combination with $\mathrm{H}_{1}$ antihistamines brings the added bonus of increasing gastric $\mathrm{pH}$ and reducing gastric volume. ${ }^{92}$ Thus, they can prevent the risk of acid aspiration or aspiration pneumonitis in groups at risk (e.g., grossly obese patients, obstetric patients, children, or patients undergoing major abdominal surgery). ${ }^{92}$

5. Mental confusion: This effect of $\mathrm{H}_{2}$-receptor antagonists has been observed in chronically ill patients with renal and hepatic failure, especially after the full dose for prevention of stress ulceration in intensive care units (ICU). ${ }^{92,93}$ This effect, however, can be expected only after treatment for several days and, hence, does not play a role in a single dose of antihistamines before operations. ${ }^{92}$

\section{Effectiveness of a Combined Prophylaxis with $\mathrm{H}_{1^{-}}+\mathrm{H}_{2}$-receptor Antagonists to Prevent Histamine Release Reactions (Pseudoallergic/Allergic Reactions) during the Perioperative Period}

A series of randomized clinical trials have demonstrated clearly that histamine release reactions of all degrees and severity are associated with the various phases of the induction of anesthesia, intraoperative measures, or drug delivery. In these trials, the effectiveness of a combined $\mathrm{H}_{1^{-}}+\mathrm{H}_{2}$-premedication was proven (Table 7). ${ }^{94-100}$ The first of these trials was performed as long ago as $1977 . .^{25}$ Since then, this premedication has been shown to be totally effective against anaphylactoid adverse drug reactions of at least grade 2 severity (systemic reactions). However, there has been a reluctance to use this strategy despite its documented effectiveness in clinical trials. ${ }^{26}$ The reason for this reluctance is not completely clear in the same way as is the reluctance to accept the high incidence of histamine release and histamine release reactions (see Introduction).

The first argument frequently raised against the use of antihistamine prophylaxis is that many mediators other than histamine are released from mast cells and basophils. Thus, antihistamine prophylaxis would be expected to be effective only against reactions mediated by histamine. This line of reasoning is not sustained by clinical experience in which it is documented that the incidence and severity of reactions are greatly reduced even in situations where histamine is not the predominant causal factor. ${ }^{31,97.100}$ However, in vitro studies have shown that antihistamines in low concentrations are able to inhibit histamine release from mast cells and to protect rat erythrocytes against osmotic shock, probably by stabilizing the cell membranes. ${ }^{101}$ The combination of $\mathrm{H}_{1^{-}}+\mathrm{H}_{2}$-receptor antagonists led to a synergistic enhancement of the inhibition. These findings have been supported by animal studies in vivo. ${ }^{21.80}$ In Table 6, the reduction in histamine release is up to $80 \%$. In a controlled clinical trial investigating reactions to atracurium, similar findings were first reported for the clinical situation. ${ }^{40}$ In the placebo group, $65 \%$ of patients responded to atracurium with a measurable clinical syndrome, a histamine release reaction. 'These reactions were reduced to $15 \%$ by the use of $\mathrm{H}_{1^{-}}+\mathrm{H}_{2}$-receptor antagonists. More histamine release without clinical symptoms was observed in the $\mathrm{H}_{1^{-}}+\mathrm{H}_{2}$-group, but the extent of the histamine release was markedly reduced. Since histamine release is involved in the process of liberating or forming other mediators, ${ }^{102}$ inhibition of histamine release also prevents the release of other mast cell-derived mediators. All of these findings provide a rationale for the use of $\mathrm{H}_{1^{-}}+\mathrm{H}_{2^{-}}$ receptor antagonists, even in situations where histamine is not the predominant mediator involved in the reaction (such as in gelatine plasma substitutes and morphine) $)^{31}$ but also in nonanaphylactic reactions, or even after complement activation by radiographic contrast media. . $^{3.97-99}$

The second argument frequently proposed is that this premedication is not strong enough for lifethreatening reactions. This speculation was clearly shown to be false with data from a number of animal experiments (Table 6). ${ }^{21,80}$ It was, however, also shown to be false in a large prospective study on chemonucleolysis by chymopapain in 31,585 patients (Table 7). ${ }^{1011}$

J. Clin. Anesth., vol. 2, September/October 1990 
Table 7. Clinical Trials Investigating the Effectiveness of a Combined Prophylaxis with $H_{1}-$ and $H_{--r e c e p t o r ~}$ Antagonists to Prevent Adverse Pseudoallergic/Allergic Reactions

Drug, Severity of Reactions, Number of Patients, Antihistamines Used
Result

Author and

Reference Number

Philbin et al."

Cardiac index (CI) unchanged, diastolic

blood pressure (DP) slightly reduced (7 torr)

$\mathrm{H}_{1}+\mathrm{H}_{2}$

CI increased, DP reduced by ca. 26 torr

saline, $p<0.05$

4/16 with flush $\mathrm{H}_{\mathrm{t}}+\mathrm{H}_{2}$

11/16 flush saline

tachycardia significantly reduced in

$\mathrm{H}_{1}+\mathrm{H}_{2}$ group

$p<0.02$

$1 / 20$ had increased $\mathrm{HR}>9$ beats $/$ min $\left(\mathrm{H}_{1}+\right.$

$\left.\mathrm{H}_{2}\right) 9 / 20$ (saline), 6/20 $\left(\mathrm{I}_{1}\right) p<0.01 \mathrm{I}_{1}+\mathrm{H}_{2}$ v. saline
$H_{1}+H_{2}$ reduced decrease in SVR caused by tubocurarine

$p<0.05$

24 patients (placebo, $\mathrm{H}_{1}, \mathrm{H}_{2}, \mathrm{H}_{\mathbf{1}}+\mathrm{H}_{2}$ ),

cardiac surgery

chlorpheniramine $0.1 \mathrm{mg} / \mathrm{kg}$

cimetidine $4 \mathrm{mg} / \mathrm{kg}$

Atracurium, grade $1+2$

40 paticnts, general surgery

dimetindene $0.1 \mathrm{mg} / \mathrm{kg}$

ranitidine $1.25 \mathrm{mg} / \mathrm{kg}$

Polygeline, grade $1+2$

50 volunteers

dimetindene $0.1 \mathrm{mg} / \mathrm{kg}+$

cimetidine $5 \mathrm{mg} / \mathrm{kg}$

Polygeline, grade 1

300 patients, orthopedic surgery

dimetindene $0.1 \mathrm{mg} / \mathrm{kg}$ or chlorpheniramine

$0.3 \mathrm{mg} / \mathrm{kg}+$ cimetidine $5 \mathrm{mg} / \mathrm{kg}$
0/20 histamine release reactions $H_{1}+H_{2}$ $10 / 20$ reactions saline

$p<0.01$

$0 / 25$ reactions $H_{1}+H_{2}$

$9 / 25$ reactions saline

$p<0.01$

4/150 reactions $H_{1}+H_{4}$ $27 / 150$ reactions saline $p<0.005$
Inada et al. ${ }^{\prime 2}$

Doenicke el al."'

Schöning et al. ${ }^{p /}$

Schöning et al."t

Beyer et al. ${ }^{97}$

$1 / 100$ mild reaction $H_{1}+H_{2}$

$5 / 100$ reactions saline

$p<0.05$

dimetindene $0.1 \mathrm{mg} / \mathrm{kg}+$ cimetidine

$5 \mathrm{mg} / \mathrm{kg}$

Urography, Telebrix, grade $1+2$

500 patients, urology

dimetindene $0.1 \mathrm{mg} / \mathrm{kg}+$ cimetidine

$5 \mathrm{mg} / \mathrm{kg}$

Urography, amidotrizoate, grade $1+2$

196 patients $H_{1}+H_{2}, 194$ patients saline,

urology

clemastine $0.03 \mathrm{mg} / \mathrm{kg}$ + cimetidine $5 \mathrm{mg} / \mathrm{kg}$

Palacos implantation, grade $1-3$

20 patients, emergency surgery

clemastine $4 \mathrm{mg}+$ cimetidine $400 \mathrm{mg}$
$16 / 300$ reactions $\mathrm{H}_{1}+\mathrm{H}_{2}$

$76 / 200$ reactions saline

less severe reactions with $\mathbf{H}_{1}+\mathbf{H}_{2}$

$4.6 \%$ incidence saline

$p<0.05$

Changes in systolic blood pressure (SP) and $\mathrm{DP}$ and number of therapeutic interventions reduced with $\mathrm{H}_{1}+\mathrm{H}_{2}$ $p<0.01$ (BP), $p<0.05$ (interventions)
$1 \%$ incidence with $\mathrm{H}_{1}+\mathrm{H}_{2}$ 
Table 7. Continued

\begin{tabular}{lll}
\hline $\begin{array}{c}\text { Drug, Severity of Reactions, Number of } \\
\text { Patients, Antihistamines Used }\end{array}$ & Kesult & $\begin{array}{c}\text { Author and } \\
\text { Reference Number }\end{array}$ \\
\hline Chymopapain, chemonucleolysis, & $15.4 \%$ anaphylactic reactions resultcd in & Moss ct al. ${ }^{\text {'tu' }}$ \\
grade 3,2 study periods: & death (I) & $1.6 \%$ anaphylactic reactions resulted in \\
I $\mathrm{n}=1585$ patients without $\mathrm{H}_{1}+\mathrm{H}_{2}$ & death (II) & $p<0.05$ \\
II $\mathrm{n}=30,000$ patients with $\mathrm{H}_{1}+\mathrm{H}_{2}$ & &
\end{tabular}

Trials listed in the sequence of their common use in anesthesia and surgery. All trials except the last were randomized controlled trials. $\mathrm{DSA}=$ digital subtraction angiography; $\mathrm{SVR}=$ systemic vascular resistance; Ultravist ${ }^{\mathrm{B}}=$ iopromide; Telebrix $^{\mathrm{R}}=$ ioxithalamate .

\section{Rationale for a Combined Prophylaxis with $\mathrm{H}_{1}$ - and $\mathrm{H}_{2}$-receptor Antagonists in Anesthesia and Surgery}

In all epidemiological and prospective studies reported (for individual data see refs. 5,9,10,21,28, $40,103,104$ ), life-threatening adverse reactions (grade 3 ) in which histamine release is causally involved ${ }^{31}$ occur in $0.1 \%-0.5 \%$ of all patients undergoing general anesthesia and surgery. This incidence comprises approximately 15,000 patients per year in West Germany,,$^{55}$ but similar data have been reported for the United Kingdom. ${ }^{103,104}$ Data from the Sheffield-based National Adverse Anesthetic Reactions Advisory Service (NAARAS) in the U.K. suggest "something between 5,000 and 10,000 clinically severe reactions each year in every European country." 103 These incidences of adverse reactions are in the same order of magnitude as perioperative thromboembolism, clinically severe bleeding from stress ulceration, and sepsis, all of which have led to prophylactic measures in a substantial proportion of surgical patients. ${ }^{40,105}$ However, cardiovascular instability observed in medium (systemic grade 2 ) reactions, which occur with an incidence of between $1-5 \%,{ }^{21,28}$ are also undesirable and should be thoroughly considered..$^{21}$ More often than supposed, anesthetists treat with fluids, vasopressors, atropine, and other measures in cardiovascular reactions which, after plasma histamine analysis, are shown to be histamine release reactions. ${ }^{40}$ Even minor increases in plasma histamine levels, in combination with other mediators, can increase morbidity and mortality, as shown for polytrauma, ${ }^{45,47} \mathrm{sep}-$ tic shock, ${ }^{44}$ after administration of radio contrast media, ${ }^{31}$ or after administration of chymopapain. ${ }^{37}$ Thus, both histamine release and the adverse reactions should be prevented. What approaches can be taken?

The first step could be discarding all drugs known to release histamine. Some drugs have been removed from the market (propanidid, Althesin ${ }^{\circledR}$ ). However, the number of drugs involved is so large that this option is not a viable solution.

The second step could be product improvement so that less histamine release occurs. This option was chosen for the plasma substitute polygeline. ${ }^{55}$ The original product was produced with a great excess of hexamethylene diisocyanate and caused severe reactions. The new formulation of purified polygeline (Haemaccel-35 ${ }^{\circledR}$ ) is produced with only a slight excess of hexamethylene diisocyanate over the stochiometric ratios and causes fewer, less severe reactions.

The third step is to discard histamine-releasing solvents. The reactions are not always caused by the drug itself; often solvents such as Cremophor $\mathrm{El}^{\circledR}$ are to blame. For example, propofol (Diprivan $\left.{ }^{\circledR}\right)$ is now formulated with the IV fat emulsion Intralipid ${ }^{\circledR}$ instead of Cremophor $\mathrm{El}^{\otimes}$, and the incidence of severe reactions is decreased. Again, however, this option is not viable in all cases.

The fourth step is more careful drug administration. Rapid bolus injections produce significantly more histamine release than do shorter administrations. This finding has been demonstrated for thiopental, propanidid, ${ }^{23}$ and the $\mathrm{H}_{2}$-receptor antagonist cimetidine.$^{61}$ Rapid injections should be avoided as much as possible. The practice of administering drugs via the same cannula without flushing can produce precipitates, causing, for example, complement activation via the alternate pathway. ${ }^{103}$

The above mentioned four measures to prevent reactions involve only single drugs. However, in anesthesia many drugs are used concurrently (e.g., analgesics, hypnotics, muscle relaxants). Many different single agents from each group are available. The use of different combinations of drugs can result in more reactions than can the use of only one single agent. The combinations can cause a potentiation of the histamine-release response or a histamine-release response when the single agents themselves cause no reaction. Thus, the four measures are in most cases 
not only unviable but also cannot guarantee prevention of the reactions. The final step, which the authors have consistently recommended for the last 15 years, is a prophylaxis with histamine $\mathrm{H}_{1^{-}}+\mathrm{H}_{2}$-receptor antagonists. Histamine release reactions have not decreased in the previous 10 years, as the authors long ago predicted..$^{96}$ This fact is attributed to the use of new drug combinations (e.g., lormetazepam-etomidate, nalbuphine, and other induction agents, as shown in this article) or the use of new drugs such as atracurium and also vecuronium, which have a high or, in the case of vecuronium, substantial incidence of histamine release. ${ }^{103.104}$ In addition, histamine release occurs after physical stress (e.g., intubation, endoscopy), during operations, by blood transfusion, etc. The authors have observed three to four separate occasions of histamine release during the preparation of single patients: ${ }^{10} .15$ during peripheral access, after alcuronium, fentanyl, suxamethonium in combination with intubation and volatile anesthetics, plasma substitutes, and, especially frequently, after the antibiotic $^{65}$ given just before skin incision. Finally, following $\mathrm{H}_{1^{-}}+\mathrm{H}_{2}$-prophylaxis, drugs which, except for their histamine releasing effects were well tolerated, can be used again instead of drugs whose side effects may be more difficult to cope with.

\section{Classification of Patients for Whom $\mathrm{H}_{1^{-}}+$ $H_{2}$-prophylaxis Should Be Recommended}

If practitioners do not want to give every surgical patient this prophylaxis, how can patients who are at risk for a more frequent or more severe reaction than

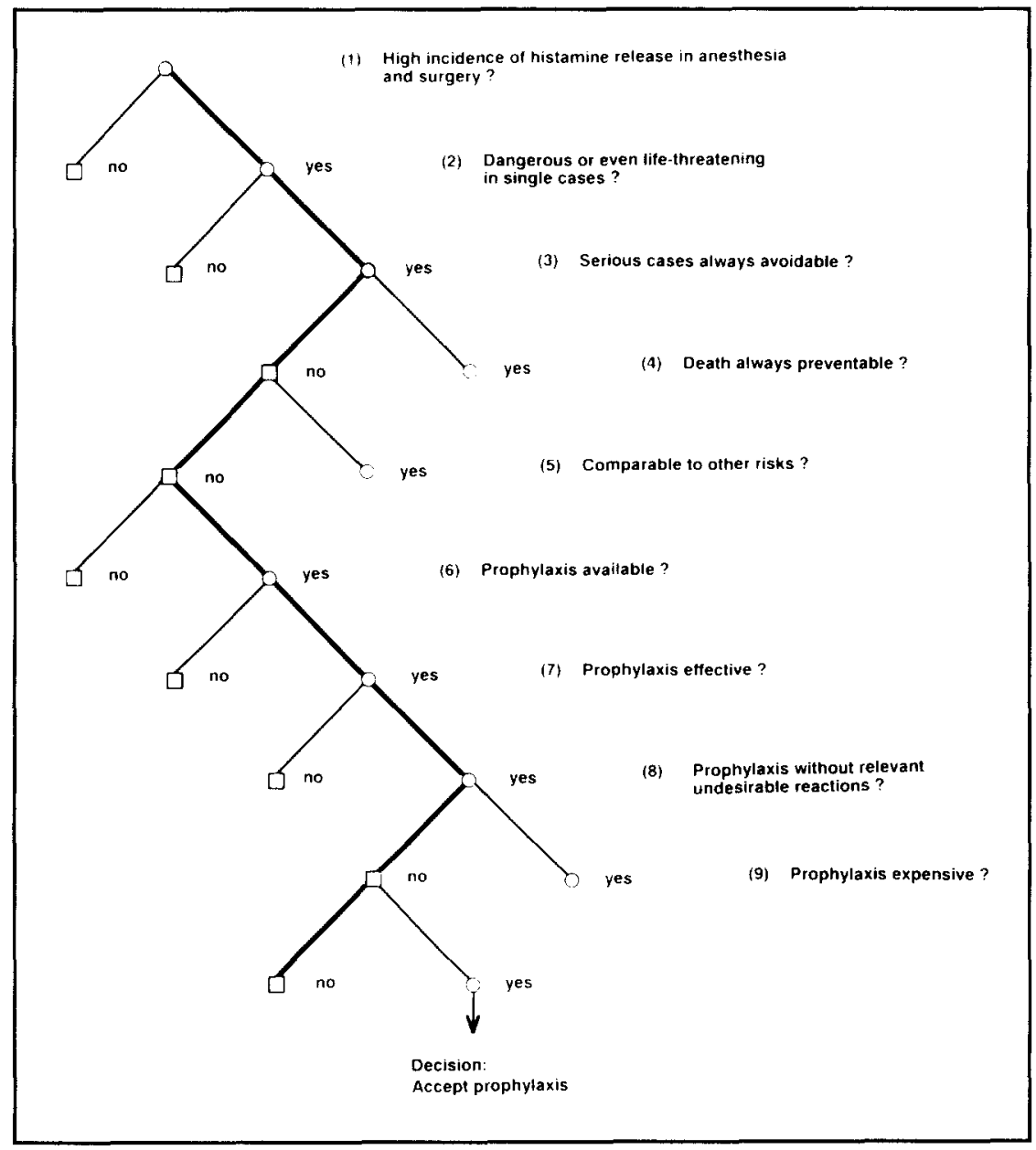

Figure 2. Decision tree for heuristic decision making developed by the "thinkaloud technique" with three experts. It includes nine hierarchically ordered decision nodes at which questions had to be answered. Data from different types of clinical studies such as controlled trials, epidemiological surveys, postmarketing surveillance studies, and cost-effectiveness analysis were used in creating this tree. The final decision was acceptance of the prophylaxis. ${ }^{105}$ 
are normal patients be defined? The authors cite a number of indications which have been determined by heuristic decision making ${ }^{21}$ and by using a decision tree (Figure 2). ${ }^{105}$ Prophylaxis with $\mathrm{H}_{1^{-}}+\mathbf{H}_{2}$-receptor antagonists should be used or at least considcred: (1) in patients with a history of adverse drug reactions or history of allergy; (2) in patients who undergo surgery with a high risk of histamine release (transplantation, extracorporeal circulation, bone cement implantation); and ( 3 ) in patients $>70$ years and those with poor physical status ( $>$ ASA 3).

Histamine is highly arrhythmogenic. It supports existing arrhythmias and potentiates an increased pulmonary shunt volume, especially in liver cirrhosis. ${ }^{21}$ Histamine is more effective in hypovolemic patients. ${ }^{44}$ It was the probable cause of death in an 80-year-old woman undergoing bone cement implantation. ${ }^{55}$ Histamine potentiates coagulation. Hence, it is conceivable that elderly patients and those with poor physical states suffer from more severe reactions to histamine than do healthy and fit subjects undergoing elective surgery.

\section{Mode of Administration of $\mathrm{H}_{\mathrm{1}^{-}}+$ $\mathrm{H}_{2}$-prophylaxis Recommended at Present}

When $\mathrm{H}_{1}-+\mathrm{H}_{2}$-prophylaxis is administered, the following conditions for drug administration are used: a slow infusion (about 3-4 minutes) of the $\mathrm{H}_{1^{-}}+\mathrm{H}_{2^{-}}$ receptor antagonist dimetindene in a dose of $0.1 \mathrm{mg} /$ $\mathrm{kg}$ and the $\mathrm{H}_{2}$-receptor antagonist cimetidine in a dose of $5 \mathrm{mg} / \mathrm{kg}$ at least 10 minutes before the induction of anesthesia. This protection lasts for more than 2 hours. ${ }^{21.80}$ Less experience is available with ranitidine, ${ }^{40}$ but a dose of $1.25 \mathrm{mg} / \mathrm{kg}$ IV was also found to be effective.

\section{References}

1. Lorenz W, Doenicke A, Meyer R, et al: Histamine release in man by propanidid and thiopentone: pharmacological effects and clinical consequences. $\mathrm{BrJ} \mathrm{An}$ aesth 1972:44:355-69.

2. Doenicke $\Lambda$, Lorenz W, Beigl R, et al: Histamine release after intravenous application of short-acting hypnotics: a comparison of etomidate, althesin (CT 1341) and propanidid. Br J Anaesth 1973;45:10971104.

3. Fisher MM: Severe histamine mediated reactions to intravenous drugs used in anaesthesia. Anaesth Intensive Care 1975;3:180-97.
1. Thornton JA: Adverse Reactions to Anaesthetic Drugs. Amsterdam: Elsevier, 1981;1-336.

5. Ahnefeld FW, Doenicke A, Lorenz W: Histamine and antihistamines in anaesthesia and surgery. Klin Wochenschr 1982;60:871-1062.

6. Moss J, Rosow CE: Histamine release by narcotics and muscle relaxants in humans. Anesthesiology 1983; 59:330-9.

7. Moss J: Vasoactive amines. Clin Anaesth 1984;2:267446.

8. Sage DJ (ed.): Anaphylactoid reactions in anaesthesia. In: International Anesthesiology Clinics. Boston: Little, Brown and Co., 1985;23:1-193.

9. Fisher MM: Adverse reactions. Clin Anaesth 1984; 2:447-697.

10. Laxenaire MC: Prevention of anaphylactoid anaesthetic reactions. Ann Fr Anesth Reanim 1985;4:99-244.

11. Lorenz W: Histamine release in man. Agents Actions 1975:5:402-16.

12. Lorenz W, Doenicke A: Histamine release in clinical conditions. Mt Sinai J Med 1978;45:357-86.

13. Douglas WS: Histamine and 5-hydroxytryptamine (serotonin) and their antagonists. In Goodman LS, Gilman A, Rall TW, Murad F (eds): The Pharmacological Basis of Therapeutics, seventh ed. New York: MacMillan Publishing Co., 1985;604-38.

14. Uvnäs B: Histamine and histamine anlagonists. In: Uvnäs B (ed): Handbook of Experimental Pharmacology. Heidelberg: Springer Verlag (in press).

15. Watkins J, Ward AM: Adverse Responses to Intravenous Drugs. London: Academic Press, 1978;1-188.

16. Kazimierczak W, Diamant B: Mechanisms of histamine release in anaphylactic and anaphylactoid reactions. Prog Allergy 1978;24:295-365.

17. Dukor P, Kallos P, Schlumberger HD, West GB: Pseudo-Allergic Reactions: Vol I. Genetic Aspects and Anaphylactoid Reactions. München: S Karger, 1980;1-307.

18. Settipane GA: $H_{1}$ and $H_{2}$ histamine receptors. Nalional Symposium, Brown University. $\mathrm{N}$ Engl Reg Allergy Proc 1984;5:300-41; 1985:6:21-83; 1985; $6: 174-200$.

19. Lorenz $\mathrm{W}$ : Hypersensitivity reactions induced by anaesthetic drugs and plasma substitutes: influence of paradigms on incidence and mechanisms. In: Gibson GG, Hubbard R, Parke DV (eds): Immunotoxicology. London: Academic Press, 1983;283-305.

20. Wolff A, Levi R: Histamine and cardiac arrhythmias. Circ Res 1986;58:1-16.

21. Lorenz W, Doenicke A: $\mathbf{H}_{1^{-}}+\mathbf{H}_{2}$-blockade: a prophylactic principle in anesthesia and surgery against histamine-release responses of any degree of severity. $N$ Engl Reg Allergy Proc 1985; Part I 6:37-57; Part II 6:174-94.

22. Lorenz W, Doenicke A: Histamine release induced by anaesthetic drugs or their solvents: nonspecific or specific? Ann Fr Anesth Reanim 1985;4:115-23.

23. Lorenz W, Doenicke A, Meyer R, et al: An improved method for the determination of histamine release in 
man: its application in studies with propanidid and thiopentone. Eur J Pharmacol 1972; 19:180-90.

24. Doenicke A, Lorenz W: Histaminfreisetzung und anaphylaktoide Reaktionen bei i.v. Narkosen. Biochemische und klinische Aspekte. Anaesthesist 1970; 19:413-17.

25. Lorenz W, Doenicke A, Dittmann I, Hug P, Schwarz. B: Anaphylaktoide Reaktionen nach Applikation von Blutersatzmitteln beim Menschen: Verhinderung dieser Nebenwirkung von Haemaccel durch Prämedikation mit $\mathrm{H}_{1^{-}}+\mathrm{H}_{2}$-Rezeptorantagnoisten. Anaesthesist 1977;26:644-48.

26. Lorenz W, Dick W, Junginger T, et al: Induction of anaesthesia and perioperative risk: influence of antihistamine $\mathrm{H}_{1^{-}}+\mathrm{H}_{2}$-prophylaxis and volume substitution with Haemaccel-35 on cardiovascular and respiratory disturbances and histamine release. Theor Surg 1988;3:55-77.

27. Hobsley M, Moss J, Gross SS, et al: Discussions about a protocol of a controlled clinical trial: Induction of andesthesia and perioperative risk. Theor $5 u r g$ 1988; $3: 132-151$.

28. Lorenz W, Doenicke A, Schöning B, Olımann C, Grote $B$, Neugebauer E: Definition and classification of the histamine-release response to drugs in anaesthesia and surgery: studies in the conscious human subject. Klin Wochenschr 1982;60:896-913.

29. Ennis M, Lorenz W: Hypersensitivity reactions induced by anaesthetics and plasma substitutes. In: Dean JH (ed): Immunotoxicology and Immunopharmacology. New York: Raven Press, 1985;457-74.

30. Watkins J: Allergic and pseudoallergic mechanisms in anaesthesia. In Sage DJ (ed.): International Anesthesiology Clinics. Boston: Little, Brown, and Co 1985;23:1740 .

31. Lorenz W, Röher HD, Doenicke A, Ohmann C: Histamine release in anaesthesia and surgery: a new method to evaluate its clinical significance with several types of causal relationship. Clin Anaesthesiol 1984; 2:403-26.

32. Ennis M, Lorenz W, Gerland W: Modulation of histamine release from rat peritoneal mast cells by noncytotoxic concentrations of the detergents cremophor El (oxethylated castor oil) and triton $\times 100$. A possible explanation for unexpected adverse drug reactions? Agents Actions 1986;18:235-38.

33. Marath A, Man W, Taylor KM, et al: Plasma histamine profiles in pediatric cardiopulmonary bypass. Agents Actions 1988;23:339-42.

34. Adt M, Reimann H-J, Schmucker P, Kuppel H, Weinhold C: Effects of preservative-free heparin on plasma histamine concentration and on hemodynamics in patients undergoing aortocoronary bypass surgery. J Cardiovase Surg 1989;30:249-56.

35. Ohmann C, Lorenz W, Ennis M, Yang Quin, Zaczyk $\mathrm{R}$, Schöning B: Computer-aided predictions of pseudoallergic reactions to plasma substitutes: a model using Haemaccel. In: Koller S, Reichertz PL, Überla K (eds): Medizinische Informatik und Statistik. Berlin: Springer-Verlag, 1985;410-20.

36. Schöning $\mathrm{B}$, Koch $\mathrm{H}$ : Pathergiequote verschiedener Plasmasubstitute an Haut und Respirationstrakt orthopädischer Patienten. Anaesthesist 1975;24:507-16.

37. Kaliner M, Sigler R, Summers R, Shelhamer JH: Effects of infused histamine: analysis of the effects of $\mathbf{H}_{1^{-}}+\mathbf{H}_{2}$-histamine receptor antagonists on cardiovascular and pulmonary responses. I Allergy Clin Immunol 1981;68:365-71.

38. Kaliner M, Shelhamer JH, Ottensen EA: Effects of infused histamine: correlation of plasma histamine levels and symptoms. J Allergy Clin Immunol 1982; 69:283-9.

39. Lorenz W, Doenicke A, Dietz W: Release of histamine by $\mathrm{H}_{2}$-receptor antagonists. Lancet 1987;2:1098.

40. Doenicke A, Lorenz W, Dick W, et al: Histamine release by atracurium and $\mathrm{H}_{1}-+\mathrm{H}_{2}$-blockade with dimetindene and ranitidine: solving a problem by asking new questions? Br / Anaesth (submitted).

11. Pearce FL: Functional heterogeneity of mast cells from different species and tissues. Klin Wochenschr 1982; 60: $: 954-57$

42. Inada E, Philbin DM, Machaj V, et al: Histamine antagonists and d-tubocurarine-induced hypotension in cardiac surgical patients. Clin Pharmacol Ther 1986; 40:575-580.

43. Granata AR, Reis DJ: Hypotension and bradycardia elicited by histamine into the CJ area of the rostral ventrolateral medulla. Eur.J Pharmacol 1987; 136:15762.

44. Lorenz W, Diet 2 W, Ennis M, Stinner B, Docnicke A: Histamine in anaesthesia and surgery: causality analysis. In: Uvnäs B (ed): Handbook of Experimental Pharmacology. Heidelberg: Springer-Verlag (in press).

45. Ennis M, Sangmeister M, Neugebauer E, et al: Plasma histamine levels in polytraumatized patients. Agents Actions 1990;30:271-73.

46. Dietz W, Lorenz W, Rothmund M, Neugebauer E, Stöltzing H, Doenicke A: Elevated plasma histamine levels in emergency patients (septic shock) and preoperative stress (endoscopy): variability as risk. Langenbecks Arch Chir Suppl Chir Forum 1988;279-84.

47. Sattler J, Lorenz W, Lindlar R, Schäfer U: Histamine in duodenal ulcer, stress-induced lesions and upper gastrointestinal bleeding: causality analysis. In: Uvnäs B (ed): Handbook of Experimental Pharmacology. Heidelberg: Springer-Verlag (in press).

48. Kusche J, Lorenz W, Stahlknecht C.-D., et al: Intestinal diamine oxidase and histamine release in rabbit mesenteric ischemia. Gastroenterology 1981;80:980-87.

49. Lindlar R, Lorenz W, Stöltzing H, Thon K, Wagner P: Plasma histamine levels in patients before endoscopy: a comparison between healthy controls and patients with duodenal ulcer, oesophageal varices and after SPV. Hepatogastroenterol 1989;36:48.

50. Lorenz W, Seidel W, Doenicke A, et al: Elevated plasma histamine concentrations in surgery: causes and clinical significance. Klin Wochenschr 1974;52:419-25. 
51. Watkins J, Thornton JA: Immunological and nonimmunological mechanisms involved in adverse reactions to drugs. Klin Wochenschr 1982;60:958-64.

52. Philbin DM, Moss J, Rosow CE, Akins CW, Rosenberger $\mathrm{JL}$ : Histamine release with intravenous narcotics: protective effects of $\mathrm{H}_{1^{-}}+\mathrm{H}_{2}$-receptor antagonists. Klin Wochenschr 1982;60:1056-59.

53. Suttmann H, Doenicke A, Lorenz W, et al: Is perioperative stress a real surgical phenomenon or merely a drug-induced effect? Theor Surg 1986;1:119-35.

54. Lorenz W, Röher HD, Doenicke A, et al: Systemic and local changes of histamine concentrations in plasma and wound exudates in the perioperative period. Clin Res Rev 1984;4:151-54.

55. Doenicke A, Ennis M, Lorenz W: Histamine release in anaesthesia and surgery: a systematic approach to risk in the perioperative period. In: Sage DJ (ed): Anaphylactoid Reactions in Anesthesia. International Anesthesiology Clinics. Boston: Little, Brown and Co., 1985;23:41-66.

56. Scott RPF, Savarese JJ, Basta SJ, et al: Atracurium: clinical strategies for preventing histamine release and attenuating the haemodynamic response. $\mathrm{BrJ}$ Anaesth $1985 ; 57: 550-53$.

57. Barnes PK, DeRenzy-Martin N, Thoman VJE, Watkins J: Plasma histamine levels following atracurium. Anaesthesia 1986;41:821-24.

58. Lorenz W, Doenicke A: Anaphylactoid reactions and histamine release by intravenous drugs used in surgery and anaesthesia. In: Watkins J, Ward AM (eds): Adverse Response to Intravenous Drugs. London: Academic Press, 1978;83-112.

59. Moss J, Philbin DM, Rosow CE, Basta SJ, Gelb C, Savarese JJ: Histamine release by neuromuscular blocking agents in man. Klin Wochenschr 1982;60: 891-5.

60. Doenicke A, Lorenz $\mathrm{W}$ : Histamine release in anaesthesia and surgery, premedication with $\mathrm{H}_{1^{-}}+\mathrm{H}_{2^{-}}$ receptor antagonists: indications, benefits and possible problems. Klin Wochenschr 1982;60:1039-45.

61. Lorenz W, Doenicke A, Schöning B, et al: $\mathbf{H}_{\mathbf{1}^{-}}+\mathbf{H}_{2^{-}}$ receptor antagonists for premedication in anaesthesia and surgery: a critical view based on randomized clinical trials with Haemaccel and various anti-allergic drugs. Agents Actions 1980;10:114-24.

62. Horrow JC: Adverse reactions to protamine. In: Sage DJ (ed): Anaphylactoid Reactions in Anesthesia. Boston: Little, Brown and Co., 1985;133-44.

63. Morel DR, Zapol WM, Thomas SJ, et al: C5a and thromboxane generation associated with pulmonary vaso- and bronchoconstriction during protamine reversal of heparin. Anesthesiology 1987;66:597-604.

64. Levy JH, Kettlekamp N, Goertz P, Hermens J, Hirshman CA: Histamine release by vancomycin: a mechanism for hypotension in man. Anesthesiology 1987; 67:122-25.

65. Dick W, Lorenz W, Junginger TH, et al: Pilot study of the Mainz-Marburg-Trial on induction of anaesthesia and perioperative risk. Theor Surg (in press).
66. Heintz D, Dick W, Lorenz W, et al: Modelierung der Histaminfreisetzung bei der Einleitung von Kombinationsnarkosen mit Nalbuphin versus Fentanyl: eine randomisierte kontrollierte klinische Studie. Anaesthesist (in press).

67. Beger HG, Stopik D: Histamine release and hepatic elimination of histamine following abdominal surgery. Klin Wochenschr 1982;60:935-38.

68. Röher HD, Lorenz W, Lennartz $\mathrm{H}$, et al: Plasma histamine levels in patients in the course of several standard operations: influence of anaesthesia, surgical trauma and blood transfusion. Klin Wochenschr 1982; 60:926-34.

69. Sitter H, Lorenz W, Klotter HJ, Duda D, Buess G, Sattler J: Histamine as a factor of tissue trauma: a tool for tcchnology assessment. Agents Actions (in press).

70. Marath A, Richards P, Man W, et al: The clinical significance of elevated CSF and plasma histamine in cerebral aneurysm surgery utilizing cardiopulmonary bypass with total circulatory arrest. Agents Actions 1988;23:343-47.

71. Marath A, Man W, Taylor KM, et al: Plasma histamine profiles in pediatric cardiopulmonary bypass. Agents Actions 1988;23:339-42.

72. Tryba $\mathbf{M}$, Thole $\mathbf{H}$, Wruck $\mathrm{G}$ : Cardiovascular reactions due to histamine release during bone-cement implantation for total hip joint replacement [Abstract]. Anesthesiology 1987;67:A68.

73. Black JW, Duncan WAM, Durrant CJ, Ganellin CR, Parsons EM: Definition and antagonism of histamine $\mathrm{H}_{2}$-receptors. Nature 1972;236:385-90.

74. Bertaccini $G$, Coruzzi $G$ : Extragastric $\mathbf{H}_{2}$-receptors. In: Hirschowit $\angle$ BI, Spenney JG (eds): Receptors and the Upper GI Tract. New York: Advanced Therapeutic Communications, Inc., 1983;201-20.

75. Mannaioni PF, Fantozzi R, Giannella E, Masini E: Pathophysiological significance of the distribution of histamine receptor sub-types: a proposed dual role for histamine in inflammation and type I hypersensitivity reactions. Agents Actions 1988;24:26-34.

76. Schwartz JC: A third histamine receptor subtype: characterization, localization, and functions of the $\mathrm{H}_{3}$ receptor. Agents Actions 1990:30:13-23.

77. Arrang J-M, Garbarg M, Lancelot J.-C., et al: Highly potent and selective ligands for histamine $\mathrm{H}_{3}$-receptors. Nature 1987;327:117-123.

78. Simons FER, Simons KJ, Frith EM, et al: The pharmacokinetics and antihistaminic activity of the $\mathrm{H}_{1}$ receptor antagonist hydroxyzine. I Allergy Clin Im munol 1984;73:69-75.

79. Gengo FM, Dabronzo J, Yurchak A, Love S, Miller JK: The relative antihistaminic and psychomotor effects of hydroxyzine and atirizine. Clin Pharmacol Ther $1987 ; 42: 265-72$.

80. Dietz W, Lennartz H, Köpf I, Schmal A, Kaiser U, Lorenz W: Life-threatening anaphylactoid reactions in the perioperative period: blockade by histamine $\mathrm{H}_{1}$ $+\mathrm{H}_{2}$-antagonists or methylprednisolone? Langenbecks Arch Chir Suppl Chir Forum 1987;333-7. 
81. Ennis $M$, Lorenz $W$ : Histamine receptor antagonists. In: Parnham MJ, Bruinvels J (eds): Discoveries in Pharmacology, Vol 2. Haemodynamics, Hormones and Inflam mation. Amsterdam: Elsevier-Science Publishers, 1984; 623-45.

82. Cooper JW: $\mathrm{H}_{\mathrm{t}}$-blockers-classical antihistamines. $N$ Engl Reg Allergy Proc 1986;7:356-361.

83. Hupert C, Yacoub M, Turgeon LR: Effect of hydroxyzine on morphine analgesia for the treatment of postoperative pain. Anesth Analg 1980;59:690-6.

84. Keeri-Szanto $M$ : The mode of action of promethazine in potentiating narcotic drugs. Br J Anaesth 1974; 46:918-924.

85. Bertaccini $\mathrm{G}$, Coruzzi $\mathrm{G}: \mathbf{H}_{\mathrm{z}}$-receptor antagonists: sideeffects and adverse effects. Ital $J$ Gastroenterol $1984 ; 16: 119-125$.

86. Feldman $\mathrm{S}: \mathrm{H}_{2}$-receptor antagonists: development and application. $N$ Engl Reg Allergy Proc 1986;7:362-366.

87. Gwee MCE, Cheah LS: Actions of cimetidine and ranitidine at some cholinergic sites: implications in toxicology and anaesthesia. Life Sci 1986;39:383-88.

88. Stirt JA, Sperry RJ, DiFazi CA: Cimetidine and succinylcholine: potential interaction and effect on neuromuscular blockade in man. Anesthesiology 1988; 69:607-8.

89. O'Sullivan GM, Smith M, Morgan B, Brighouse D, Reynolds $\mathrm{F}$ : $\mathbf{H}_{2}$-antagonists and bupivacaine clearance. Anaesthesia 1988;43:93-5.

90. Noble DW, Smith KJ, Dundas CR: Effects of $\mathrm{H}_{2^{-}}$ antagonists on the elimination of bupivacaine. $B, J$ Anaesth 1987;59:735-37.

91. Dailey PA, Hughes SC, Rosen MA, Healy K, Cheek DBC, Shnider SM: Effect of cimetidine and ranitidine on lidocaine concentrations during epidural anesthesia for cesarean section. Anesthesiology 1988;69:101317.

92. Tryba $\mathbf{M}: \mathbf{H}_{2}$-Antagonisten in der Prämedikation. $A n$ aesthesie und Intensiumedizin, Vol 172. Berlin: SpringerVerlag, 1985;1-152.

93. Schentag JJ, Cerra FB, Calleri GM, Leising ME, French MA, Bernhard H: Age, disease, and cimetidine disposition in healthy subjects and chronically ill patients. Clin Pharmacol Ther 1981;29:737-43.

94. Philbin DM, Moss J, Akins CW, et al: The use of $\mathbf{H}_{1}$ $+\mathrm{H}_{4}$-histamine antagonists with morphine anesthesia: a double blind study. Anesthesiology 1981;55:29296.
95. Iryba M, Zevounou F. Zenz M: Prevention of histamine-induced cardiovascular reactions during induction of anesthesia following premedication with $\mathrm{H}_{1}$ $+\mathrm{H}_{2}$-antagonists i.m. Br J Anaesth 1986;58:478-82.

96. Schöning B, Lorenz W, Doenicke A: Prophylaxis of anaphylactoid reactions to a polypeptidal plasma substitute by $\mathrm{H}_{1^{-}}+\mathrm{H}_{2}$-receptor antagonists: synopsis of three randomized controlled trials. Klin Wochenschr $1982 ; 60: 1048-55$.

97. Beyer HK, Kukulies R, Schmitt WGH, Schulze B: Nebeneffekte und Komplikationen nach Röntgenkontrastmittelgabe-Risikoverminderung und Prävention. Röntgenpraxis 1987;40:459-65.

98. Tauber R, Reimann HJ, Kersting H, Schmidt U: Prämedikation mit $\mathrm{H}_{1^{-}}+\mathrm{H}_{2}$-Rezeptorantagonisten vor Applikation von Röntgenkontrastmitteln? Münch Med Wschr 1985;127:1052-54.

99. Ring J, Rothenberger KH, Clauss W: Prevention of anaphylactoid reactions after radiographic contrast media infusion by combined histamine $\mathbf{H}_{1^{-}}+\mathbf{H}_{2^{-}}$receptor antagonists: result of a prospective controlled trial. Int Arch Allergy Appl Immunol 1985;78:9-14.

100. Moss J, Roizen MF, Nordby EJ, Thisted R, Apfelbaum JL, McDermott DJ: Decreased incidence and mortality of anaphylaxis to chymopapain. Anesth Analg 1985; 64:1197-1201.

101. Lau HYA, Pearce FL: Effects of antihistamines on isolated rat peritoneal mast cells and on model membrane systems. Agents Actions (in press).

102. Platshon LF, Kaliner M: The effects of the immunological release of histamine upon human lung cyclic nucleotide levels and prostaglandin generation. J Clin Invest 1978;62:1113-21.

103. Watkins J, Levy CJ: Guide to Immediate Anaesthetic Reactions. London: Butterworths, 1988;1-128.

104. Watkins J: Heuristic decision making in diagnosis and management of adverse drug reactions in anaesthesia and surgery: the case of muscle relaxants. Theor Surg $1989 ; 4: 212-22$.

105. Stinner B, Dietz W, Lorenz W: "Think aloud techniquc" in medical dccision making: a new study design in estimating argued prophylactic procedures for the reduction of perioperative risk. Iangenbecks Arch Chir Suppl Chir Forum 1990;171-7. 